\title{
Bone Marrow Environment in Metastatic Neuroblastoma
}

\author{
Chiara Brignole ${ }^{1}(\mathbb{D})$, Fabio Pastorino ${ }^{1} \mathbb{D}$, Patrizia Perri ${ }^{1} \mathbb{D}$, Loredana Amoroso ${ }^{2} \mathbb{D}$, Veronica Bensa ${ }^{1}$, \\ Enzo Calarco $^{1}$ (D), Mirco Ponzoni ${ }^{1}$ (D) and Maria Valeria Corrias ${ }^{1, *(D)}$
}

1 Laboratory of Experimental Therapies in Oncology, IRCCS Istituto Giannina Gaslini, 16147 Genova, Italy; chiarabrignole@gaslini.org (C.B.); fabiopastorino@gaslini.org (F.P.); patriziaperri@gaslini.org (P.P.); veronicabensa@gaslini.org (V.B.); enzocalarco@gaslini.org (E.C.); mircoponzoni@gaslini.org (M.P.)

2 Pediatric Oncology, IRCCS Istituto Giannina Gaslini, 16147 Genova, Italy; loredanaamoroso@gaslini.org

* Correspondence: mariavaleriacorrias@gaslini.org

Citation: Brignole, C.; Pastorino, F.; Perri, P.; Amoroso, L.; Bensa, V.; Calarco, E.; Ponzoni, M.; Corrias, M.V. Bone Marrow Environment in Metastatic Neuroblastoma. Cancers 2021, 13, 2467. https://doi.org/ $10.3390 /$ cancers 13102467

Academic Editors: Alice L. Yu and Shweta Joshi

Received: 30 March 2021

Accepted: 14 May 2021

Published: 19 May 2021

Publisher's Note: MDPI stays neutral with regard to jurisdictional claims in published maps and institutional affiliations.

Copyright: (C) 2021 by the authors. Licensee MDPI, Basel, Switzerland. This article is an open access article distributed under the terms and conditions of the Creative Commons Attribution (CC BY) license (https:// creativecommons.org/licenses/by/ $4.0 /)$.
Simple Summary: In children with metastatic neuroblastoma (NB) the overall survival is still poor despite aggressive multimodal therapies. Relapse and progression, which are the major causes of death, usually occur at the most common metastatic site, the bone marrow (BM). Thus, understanding the complex interaction between the BM-infiltrating NB cells and the BM environment may help identify the mechanisms that allow survival of the metastatic cells. Moreover, new therapeutics targeting the microenvironment and/or the resistance to treatment can lead to improved survival for these children. The complexity of the BM environment and the existence of multiple mechanisms, all favoring the escape of metastatic NB cells from immune recognition, stress the need to test synergistic immune therapy approaches.

Abstract: The study of the interactions occurring in the BM environment has been facilitated by the peculiar nature of metastatic NB. In fact: (i) metastases are present at diagnosis; (ii) metastases are confined in a very specific tissue, the BM, suggestive of a strong attraction and possibility of survival; (iii) differently from adult cancers, NB metastases are available because the diagnostic procedures require morphological examination of $\mathrm{BM}$; (iv) NB metastatic cells express surface antigens that allow enrichment of NB metastatic cells by immune-magnetic separation; and (v) patients with localized disease represent an internal control to discriminate specific alterations occurring in the metastatic niche from generic alterations determined by the neoplastic growth at the primary site. Here, we first review the information regarding the features of BM-infiltrating NB cells. Then, we focus on the alterations found in the BM of children with metastatic NB as compared to healthy children and children with localized NB. Specifically, information regarding all the BM cell populations and their sub-sets will be first examined in the context of BM microenvironment in metastatic NB. In the last part, the information regarding the soluble factors will be presented.

Keywords: neuroblastoma; bone marrow; metastases

\section{Neuroblastoma}

Neuroblastoma (NB) is the second most common solid childhood tumor [1-4]. Tumors arise in the sympathetic nervous system; about $45 \%$ of cases arise in the adrenal medulla and, in the remaining cases, in the para-spinal ganglia at any possible location [5], thus, NB cells secrete the sympathetic catecholamine epinephrine and norepinephrine and their metabolites.

NB clinical presentation is highly heterogeneous, ranging from localized disease, requiring only local control by chemotherapy and surgery, to metastatic disease, present in $50 \%$ of cases already at onset, requiring multimodal aggressive treatment modalities [1-4]. Today, staging is based on the presence of surgical risk factors [6] and established prognostic factors [7]. Infant and children with NB are classified into very low-, low-, intermediateand high-risk groups depending on the age at diagnosis, with a benign effect of age below 
18 months, presence/absence of metastasis (stage $\mathrm{M}$ /stage $\mathrm{L}$, respectively), and presence of genomic aberrations at relevant loci, such as the amplification of the $M Y C N$ oncogene or the deletion of chromosome 11q [7]. The outcome of NB patients is highly variable, reflecting the heterogeneity of the clinical presentation. The 5-year overall survival (OS) ranges from $98-100 \%$ for stage $\mathrm{L}$ infants ( $<18$ months of age at diagnosis) without $M Y C N$ amplification [8] to $50 \%$ for children with stage $M$ disease [9].

In children with stage $\mathrm{M} \mathrm{NB}$, the tissues mostly involved are the bone marrow (BM) and the bone. As the majority of patients with stage $\mathrm{M} \mathrm{NB}$ present metastases already at onset, the in vivo evaluation of factors influencing BM and/or bone invasion by NB cells is quite difficult to address. However, the peculiar nature of stage M NB has facilitated the studies of the complex interactions between the metastatic NB cells and the bone and $\mathrm{BM}$ resident cells, as compared with other cancer types. According to clinical practice, morphological examination of BM smears and of bone trephine biopsies are performed at diagnosis and during treatment for metastatic disease evaluation [10-12]. These diagnostic procedures make it possible to preserve biological material for additional studies on both NB and BM resident cells. Furthermore, specific characteristics of NB cells allow the performing of biological studies, even on small quantities of biological material. In fact, NB cells selectively express surface antigens, such as the disialoganglioside GD2 [13] and the B7-H3 co-stimulatory molecules [14], that allow their enrichment by immune-magnetic separation $[15,16]$. Last and more importantly, children with localized stage L NB represent an internal control to recognize the alterations occurring in the metastatic niche from those determined by the neoplastic growth at the primary site.

Relapse or progression at the metastatic site are the major causes of death for NB [17,18], thus, understanding the complex interaction between the BM-infiltrating NB cells and the bone and BM resident cells may help identify new therapeutic targets, possibly leading to improvement of survival of children with metastatic NB.

\section{Physiological BM and Bone Environment}

$\mathrm{BM}$ is the primary site of hematopoiesis, where the self-renewal pluripotent hematopoietic stem cells (HSC) give rise, through committed precursors, to the erythroid (red cells and megakaryocytes), myeloid (granulocytes, monocytes, macrophages, and osteoclasts) and lymphoid (T, B and NK cells) lineages [19], as shown in Figure 1.

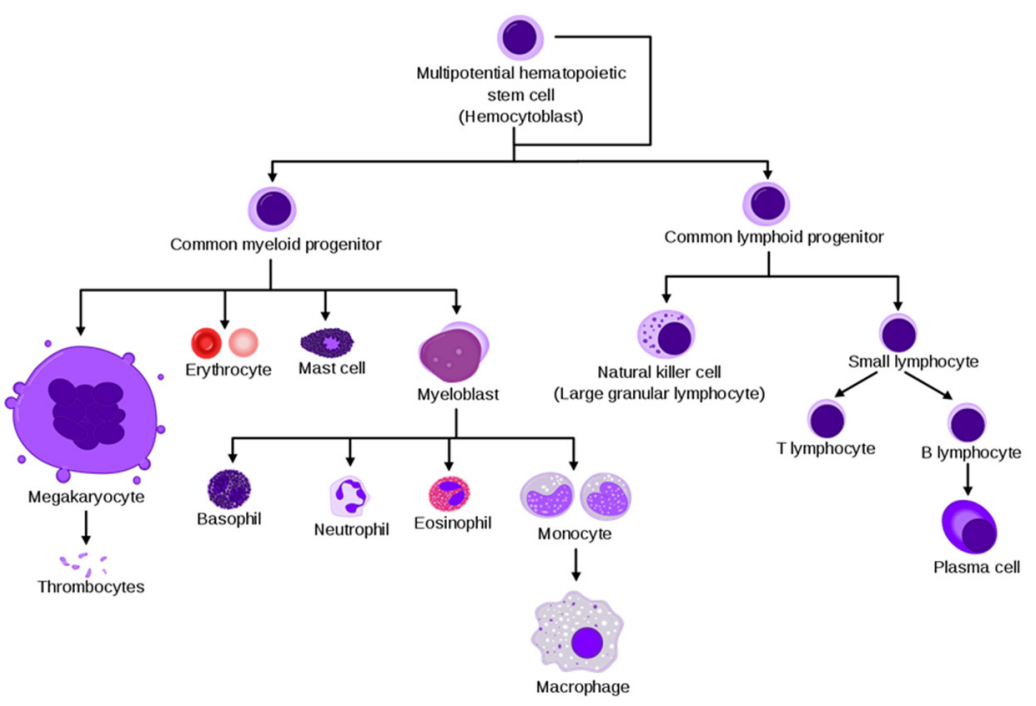

Figure 1. Simplified hematopoiesis hierarchy (Courtesy of Wikipedia).

BM also contains non-hematopoietic cells, such as endothelial, nerve and mesenchymal stromal cells (MSC) that can differentiate in adipocytes, osteoblasts or chondroblasts (Figure 2). The BM is enclosed in bone structures that are continuously remodeled thanks 
to bone resorption mediated by the myeloid-derived osteoclasts and bone regeneration mediated by the MSC-derived osteoblasts [20].

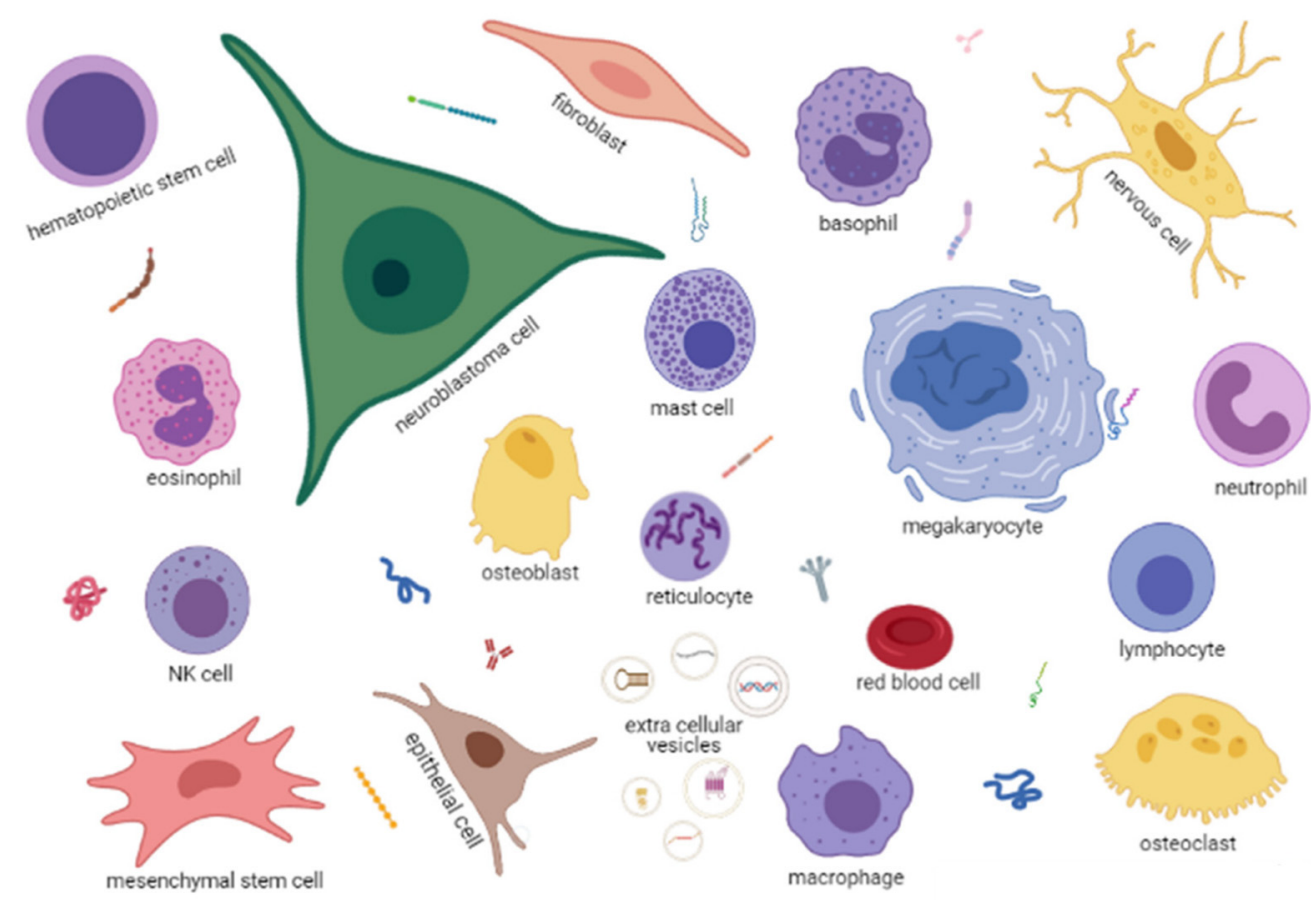

Figure 2. A cartoon, created in Biorender.com, depicting the BM microenvironment in NB. Each cell type is named in the figure. Extracellular vesicles of different dimensions with different types of cargo (DNA, miRNA, mRNA, proteins) are indicated in the bottom center of the figure. Different types of soluble proteins, such as antibodies, cytokines, enzymes etc., are scattered among the cells. Created with BioRender.com (accessed on 18 May 2021).

Each cell type expresses receptors and ligands for other cells and may secrete soluble factors, such as growth factors, cytokines and chemokines, or extracellular vesicles of different sizes with various types of cargo, such as proteins, metabolites, DNA fragments or RNA species, including mRNA, microRNA or non-coding RNA (Figure 2).

BM homeostasis is, therefore, a process involving many cross-talks between hematopoietic and non-hematopoietic cells that are partially defined. The presence in this environment of a metastatic NB cell (Figure 2), expressing receptors/ligands, releasing soluble factors and extracellular vesicles, necessarily alters the physiological homeostasis, likely favoring its survival and proliferation.

Given the complexity of the BM microenvironment in NB, in this review, we first summarize the information regarding the features of the metastatic BM-infiltrating NB cells, with special attention to the mechanisms that allow them to escape immune recognition and to the differences with primary tumor cells that can be derived from the analysis of their gene expression profile.

Then, we summarize the alterations found in each of the BM cell populations in children with metastatic NB as compared to healthy children, whereas in the last part, we focus on the large variety of soluble factors, either free or enclosed in vesicles, that can modify the interaction between BM cells and the metastatic NB cells.

\section{BM-Infiltrating Metastatic NB Cells}

BM-infiltrating NB cells can be detected by flow cytometry of BM aspirates with the combined use of an antibody directed against antigens selectively expressed by NB cells, such as GD2 and B7-H3 [13,14], and an antibody directed against the differentiation cluster (CD) 45 expressed by all hematopoietic cells [21].

The percentage of CD45-/GD2+ BM-infiltrating NB cells is highly variable, ranging from $0.5-1 \%$ to $20-30 \%$ [15,16]. BM-infiltrating NB cells can also be detected in the cytospin 
of BM aspirates by immunocytochemistry with an anti-GD2 antibody [22] and by quantitative RT-PCR analysis for NB-specific mRNAs, such as tyrosine hydroxylase (TH), the first enzyme in the synthesis of catecholamine, and the paired-like homeobox $2 \mathrm{~b}$ (PHOX2B), expressed at early stages during neuronal development [23]. Elevated levels of TH and PHOX2B mRNAs in BM aspirates from stage M NB children and infants at diagnosis are predictive of worse outcomes [24,25]. Similarly, elevated levels of a panel of 5 NB-specific mRNAs are predictive of worse progression-free survival in children with relapsed NB [26].

\subsection{Mechanisms of Tumor Escape from Immune Recognition}

BM-infiltrating NB cells, freshly isolated from BM, express co-stimulatory molecules, such as CD80, CD86, OX40L and 4-1BBL43 [27], but the absence of HLA class I molecules on the surface of NB cells, due to multifactorial mechanisms [28-30], does not allow their functional engagement by cytotoxic CD8+ T cells.

The absence of HLA class I molecules on the surface of NB cells makes them a target for NK cell cytotoxicity. NK cells, in fact, are inhibited by the engagement of inhibitory receptors of self HLA class I antigens [31]. BM-infiltrating NB cells, however, always express the co-stimulatory molecule B7-H3, a ligand for a still unknown inhibitory NK receptor that greatly reduces the killing activity of stimulated NK cells [32]. In addition, NB cells express little, if any, ligands for NK activating receptors. Precisely, most BMinfiltrating NB cells do not express PVR and DNAM molecules [33] ligand of the NKp30 and NKp44 receptors, nor the major histocompatibility complex class I-related chains, MIC-A and -B, ligands of the activating NKG2D receptor [34].

BM-infiltrating NB cells secrete the cytokine TGF- $\beta$ that modifies, in a dose-dependent manner, the expression of the chemokine receptors CXCR4, CXCR3 and CX3CR1 in NK cells present in the BM of children with NB, potentially affecting their activity [35].

Collectively, these findings demonstrated that BM-infiltrating NB cells are endowed with several mechanisms to evade both $\mathrm{T}$ and NK cell immune surveillance.

\subsection{Chemokine and Chemokine Receptors}

Chemokines are a large family of small proteins that, upon binding to their cognate receptors, induce integrin activation and cytoskeletal rearrangement, promoting cell adhesion and directional migration [36].

BM-infiltrating NB cells express a broad range of chemokine receptors, including CCR1, CCR5, CCR6, CCR9, CXCR1, CXCR2, CXCR3, CXCR4, CXCR5 and CXCR6 [37]. However, most of these receptors seem to be involved in cell-cell adhesion in the BM, rather than in the NB cell migration towards the BM. In fact, no migration occurs when BMinfiltrating NB cells are exposed to CXCL16, the ligand of CXCR6 [37], and to CXCL12/SDF1 , the ligand of CXCR4 [38]. The only functional chemokine receptors expressed by BMinfiltrating NB cells are CXCR5, responsive in vitro to its ligand CXCL13and CXCR3, responsive to CXCL10 [37]. In the latter case, engagement of CXCR3 by CXCL10 mediates suppression, rather than enhancement, of NB cell proliferation [39].

\subsection{Gene Expression Profiles}

Starting from NB infiltrated BM samples, Hansford et al. obtained highly tumorigenic tumor spheres, suggesting that metastatic cells were enriched in tumor-initiating cells (TICs), endowed with the typical stem cell indefinite proliferative potential [40]. A gene expression profile of these cells was reported [41], but later, the isolated TICs were found not to be NB cells [42]. Moreover, it was demonstrated that in vitro expanded stem-like $\mathrm{NB}$ cells were a dynamic and heterogeneous cell population, quite difficult to characterize because of the influence of external stimuli [43].

Thus, to avoid any modification or selection following in vitro culture, we and others have decided to characterize freshly isolated BM-infiltrating NB cells using magnetic beads coated with anti-GD2 or anti-CD45 antibody (positive and negative immune selection, respectively). 
GD2+/CD45- BM-infiltrating NB cells express the classical histological marker of NB, namely NB84 and CD56, and carry the same genetic alterations as the primary NB tumor cells $[15,44]$. The gene expression profile of freshly isolated BM-infiltrating NB cells has been compared to that of primary tumor NB cells [15] and to that of whole infiltrated BM samples [44]. In both cases, BM-infiltrating NB cells, also called disseminated tumor cells (DTCs), not surprisingly showed a lower expression of genes belonging to the angiogenesis and cell-cell adhesion functional annotation clusters. This finding was confirmed by the analysis of microRNA (miRNA) expression profiles of BM-infiltrating NB cells and primary tumor cells, demonstrating that the down-modulation of the focal adhesion pathway in the metastatic cells was regulated by CNOT1, a transcription regulator, through miR-659$3 p$ [45].

Regarding the genes up-regulated in freshly isolated BM-infiltrating NB cells as compared to primary NB tumor cells, both studies found a higher expression of mitochondrial genes [15,44], suggesting a higher metabolic activity of the metastatic cells. Due to the different comparative analyses performed in the two studies, Morandi et al. were able to detect in BM-infiltrating NB cells the expression of genes typically expressed by resident $\mathrm{BM}$ cells [15]. To rule out the possibility that this finding was due to inefficient immune magnetic separation leading to contamination with resident BM cells, they performed a flow cytometry analysis of unprocessed BM aspirates, which confirmed that freshly isolated BM-infiltrating NB cells always express two molecules on their cell surface, namely the HLA-G molecule and calprotectin, an heterodimer encoded by the S100A8/ A9 genes [15].

The expression of HLA-G and calprotectin by BM-infiltrating NB cells is intriguing. HLA-G is a tolerogenic HLA-class Ib molecule enabling the escape of tumor cells from immune surveillance [46]. Since HLA-G is not expressed by primary NB tumor cells [47], it can be postulated that the ability of BM-infiltrating NB cells to survive in the BM and restart proliferation after an apparent cure could be a consequence of the HLA-G immune suppressive activity.

Calprotectin is normally expressed by neutrophils and is released into biological fluids following their activation by inflammatory stimuli [48]. Calprotectin is a potent ligand of the Toll-like receptor 4 (TLR4), which is responsible for specific response to endogenous danger signals. The calprotectin-TLR4 axis was shown to drive metastatic invasion of lung cancer cells [49], but no information in NB is available. However, it can be hypothesized that calprotectin expressed by BM-infiltrating NB cells may be responsible in part for the state of chronic inflammation present in the BM environment in children with $\mathrm{NB}$, as reported in detail in the cytokines' paragraph.

\subsection{Plasticity of NB Cells: Adrenergic and Mesenchymal Phenotypes}

In the last few years, data are accumulating regarding the plasticity of NB cells and their ability to shift from an adrenergic to a mesenchymal phenotype and vice versa, under the control of core regulatory circuits regulating specific gene expression profiles [50-55]. Moreover, single-cell sequencing techniques, together with the availability of atlas describing the developmental fate of sympathetic progenitor cells [56], have allowed studies to better characterize the potential origin of neoplastic NB cells and to identify the mechanisms allowing the plasticity.

Presently, conflicting results have been published [57-61] regarding their developmental origin, but definitive results will certainly come in the next few years. As for the plasticity, it is interesting to note that already in 2007, Martinez et al. described the presence of GD2+/CD45 - cells with mesenchymal phenotype in the BM of children with NB [62]. Whether these cells are indeed metastatic NB cells presenting with a mesenchymal phenotype will certainly be addressed in the near future.

\subsection{Epithelial to Mesenchymal Transition (EMT)}

EMT is a developmental process whereby stationary, adherent cells acquire the ability to migrate, thus, EMT can drive the metastatic process. In NB, EMT is associated with 
enhanced stem cell properties and drug resistance [63]. Recently, it has been shown in in vitro models of drug-resistant adrenergic (ADRN) and mesenchymal (MES) neuroblastoma cell lines that low expression of miR-124-3p is responsible for drug resistance and higher invasive capacity [64]. The development of organoids from patient-derived NB cells growing in an extracellular matrix of defined composition [65] will certainly help to elucidate the mechanisms that control BM invasion by NB cells.

\section{BM Cellular Composition in NB}

\subsection{Lymphoid Lineage}

BM-infiltrating NB cells do not seem to affect the lymphoid lineage in general $[66,67]$, nor specific lymphocyte subsets, such as the immunosuppressive regulatory $\mathrm{T}$ cell, Treg and Tr1 [68]. No information on the features of BM NK cells is presently available, whereas an interesting lymphoid subset, the invariant NKT (iNKT) cells, has been extensively studied in NB tumors. iNKT cells express an invariant $\mathrm{T}$ cell receptor alfa chain that recognizes self or microbial glico-lipids presented by the monomorphic HLA-class I-like molecule CD1d [69]. Although NB cells do not express CD1d, iNKT cells exert their antitumor activity by killing the tumor-associated macrophages (TAM) [70]. The latter favors NB cell proliferation at the primary tumor site [71,72]. However, nothing is known regarding interactions among macrophages, iNKT cells and BM-infiltrating NB cells in the BM environment.

\subsection{Myeloid Lineage}

A particular cell of myeloid origin is represented by the osteoclasts that share with macrophages the CD115 receptor for the chemokine CCL2 [73]. NB cells suppress CCL2 expression that is necessary to promote infiltration by iNKT [74]. However, no specific information is available regarding these circuitries in the BM environment.

In NB, bone invasion by neoplastic cells seems to be predominantly osteolytic. NB cells express high levels of the receptor activator of nuclear factor-kB ligand (RANKL) that directly activates osteoclasts [75]. In addition, BM mesenchymal stem cells release several soluble osteoclast-activating factors, as detailed in the following paragraph. Bone resorption may create space for NB growth, but BM mesenchymal cells can differentiate in osteoblasts, giving rise to a vicious cycle of osteoblast and osteoclast genesis. One of the major players in this cycle is dickkopf 1 (Dkk1), an inhibitor of the canonical wingless (Wnt) pathway [76]. NB cells release Dkk1 [77], but its levels in children with NB do not associate with the presence of bone metastasis [78], making unlikely a pivotal role in NB bone invasion.

\subsection{Erythroid Lineage}

In children with $\mathrm{NB}$, the maturation of erythrocytes was found to be selectively affected at the ortho-chromic stage, resulting in reduced erythrocyte count in the periphery [67]. Since children with localized NB share the same reduction, it is likely that primary tumor, rather than BM-infiltrating NB cells are responsible for this finding [67]. This hypothesis is supported by the fact that the major functional annotation clusters (anemia, blood group antigens, and heme and porphyrin biosynthesis) found under-expressed in the $\mathrm{BM}$ of children with $\mathrm{NB}$, as compared to healthy children, were the same regardless of the presence/absence of metastatic BM-infiltrating NB cells $[67,79]$.

\subsection{Mesenchymal Stromal Cells}

Among the non-hematopoietic cells, the MSCs are the most represented. MSCs completely lack the expression of hematopoietic markers, including CD45, and express CD105, CD73 and CD90.

BM MSCs have been shown to enhance NB growth in primary NB tumors and in vitro co-culture [80-82]. Only recently, the mesenchymal cells present in the BM environment have become the subject of specific studies. Hochheuser et al. found that the presence of 
BM-infiltrating NB cells is associated with an increased number of MSCs in the BM [66]. However, the fraction of MSCs expressing CD271, a marker of clonogenicity, was reduced and the MSC ability to differentiate was skewed towards osteoblasts [66]. Similar results were reported by Colletti et al. showing a higher osteogenic potential of MSC from BM infiltrated with NB cells, as compared to healthy BM MSC [83].

Hochheuser et al. also found a particular subset of BM MSC, negative for the clonogenic CD271 marker and positive for the osteogenic CD146 marker, associated with the presence of BM-infiltrating NB cells [66]. Interestingly, this subset was present at diagnosis and at relapse and disappeared during treatment. Most importantly, their presence after induction therapy is associated with an increased risk of relapse, suggesting a potential role in inducing chemoresistance [66]. Further studies are needed to clarify whether MSC favors BM infiltration by NB cells or NB cells alter the MSC differentiation process. Moreover, the use of mesenchymal cells as tumor-selective delivery vehicles for therapeutic compounds and oncolytic viruses needs to be reconsidered [84].

Very recent data presented at the Advances in Neuroblastoma Research 2021 by Burchill et al. showed the expression of PRRX1 and periostin mesenchymal markers in bone trephine biopsies and cytospins of BM aspirates from children with stage M NB [85]. Interestingly, elevated levels of BM infiltration with periostin-expressing cells is associated with a two-fold increased risk of an event, supporting a neoplastic potential for these MSC. Thus, whether the detected MSCs are true MSCs or NB cells with mesenchymal phenotype, as reported in the BM-infiltrating NB cell paragraph, needs to be addressed.

Finally, BM MSC can also affect response to anti-GD2 immunotherapy, nowadays included in the standard of care for children with stage M NB $[86,87]$. Wu et al. recently showed that the killing of NB cells by activated NK cells, through antibody-dependent cellmediated cytotoxicity (ADCC) [88], can be suppressed by the presence of CD105-expressing BM MSC, and successfully restored by the use of an anti-CD105 antibody [89].

\section{Soluble Factors}

\subsection{Catecholamines}

Norepinephrine physiologically regulates HSC migration egress from the BM through anti-phase circadian fluctuations of Cxcl12 levels [90]. NB cells secrete norepinephrine, thus, Cxcl12 levels theoretically should be lower than in physiological conditions, potentially favoring hematopoietic cell egress. Conversely, no difference in the number of hematopoietic cells in the periphery was found [66,67], with the exception of erythrocytes [67], as reported in the erythroid lineage paragraph. These findings suggest that compensative pathways are in place in NB. In addition, we found that CXCL12 gene expression was low in all children with NB, regardless of the presence of BM-infiltrating cells [79]. Thus, the low Cxcl12 levels in the BM of NB patients seems to depend on the systemic effect of the primary tumor cells. The low Cxcl12 levels also make unlikely a pivotal role of the CXCL12/CXCR4 axis in promoting BM homing of the CXCR4 positive NB cells, as previously suggested [91]. Further supports for this conclusion are the finding, mentioned in the BM-infiltrating NB cell paragraph, that the CXCR4 receptor is not functional in those cells [38], and the results from Meier et al. that CXCR4 does not promote invasion [92].

\subsection{Cytokines}

Cytokines are proteins produced by various cell types that, following engagement of specific receptors, regulate the immune response and/or differentiation, proliferation and responsiveness of specific cell populations, mainly involved in immune responses [93].

Gene expression analysis of BM resident cells from children with NB demonstrated a significant over-expression of the interferon (IFN) and IFN-related DNA damage resistance (IRDR) signatures [79]. IFNs are pleiotropic cytokines involved in the innate immune responses against bacterial and viral pathogens. IFN- $\alpha$ and IFN- $\beta$ (IFN type I), commonly induced by pathogens, are highly potent cytokines up-regulated during inflammation, whereas IFN- $\gamma$ (IFN type II) is the master regulator of cytotoxic CD8+ T cell immune 
responses, including those against tumor cells [94]. Since the two signatures were also found in children with localized NB, it is conceivable that the primary tumor, rather than the BM-infiltrating NB, cells are responsible for the IFN-related gene up-regulation. It is interesting to note that activated NK cells secrete IFN- $\gamma$ that, in turn, induces expression of HLA-class I [95] and PD-L1 [96] in freshly isolated BM-infiltrating NB cells. The upregulation of HLA-class I would render the metastatic NB cells susceptible to cytotoxic $\mathrm{CD} 8+\mathrm{T}$ cells, but the simultaneous up-regulation of PD-L1, the ligand for the immune check point $\mathrm{PD}-1$, blocks the potential immune response.

NB cells secrete galectine- 3 that, activating the galectine receptor on BM MSCs, induces the release of IL-6 [97,98]. IL-6 is responsible for the polarization of macrophages toward an M2 phenotype that, in turn, maintains a pro-inflammatory state with potential impairment of immune-recognition.

Other important immunosuppressive cytokines are IL-10, released by the regulatory $\mathrm{T}$ cells, and Arginase-1 (ARG-1) produced by immunosuppressive CD163+ macrophages. As compared to healthy children, the expression of ARG-1 gene in BM from children with NB was similar, whereas that of IL-10 gene was increased [99]. However, the Il-10 protein levels were not predictive of outcome, making its role in NB escape from immune recognition in the BM environment unlikely.

\subsection{Monomorphic HLA Class Ib Molecules}

A peculiar type of soluble factor endowed with tolerogenic properties is represented by the monomorphic HLA-class $\mathrm{Ib}$ molecules that display a limited number of alleles able to present antigens to cytotoxic CD8+ T cells [100]. The best characterized in NB are HLA-G, already described in the BM-infiltrating NB cell paragraph, and HLA-E and HLA-F. The soluble form of HLA-E and HLA-F seems to enhance immune recognition. Elevated plasma levels of both molecules, in fact, are significantly associated with better outcomes of children with NB [101], suggesting that these molecules were released by activated immune cells. BM plasma levels of HLA-G and HLA-E at diagnosis were detected in children with NB. Their levels were higher than in healthy children, but a potential association with outcome could not be assessed due to the design of the study [102].

\subsection{Extracellular Vesicles}

Extracellular vesicles (EVs) play an important role in cell-cell communications through spontaneous or receptor-mediated endocytosis, or by direct fusion with the plasma membrane [103]. EVs also represent an important delivery system in the tumor microenvironment, facilitating bi-directional signal dissemination between cancer and resident cells [104]. EVs include exosomes and microvesicles (MVs); exosomes are smaller than MVs (40-120 nm versus $50-1000 \mathrm{~nm}$ ) and are generated through an endocytic pathway, whereas MVs are released from the plasma membrane [105]. In NB, MVs and exosomes have been isolated; both express the disialoganglioside GD2, confirming that they were released by the neoplastic NB cells $[106,107]$. EVs may be loaded with different types of cargo, as detailed below.

\subsubsection{Immunosuppressive Molecules}

A soluble molecule endowed with immunosuppressive property is adenosine (ADO) generated by ectoenzymes that metabolize ATP. Two alternative pathways, one driven by CD39 and the other by CD38, converge to the activity of CD73 that converts AMP to $\mathrm{ADO}$ [108]. Recently, ADO and the various ectoenzymes involved in the pathways have been found in BM MVs from children with NB [109]. These vesicles strongly reduced the proliferation of $\mathrm{T}$ cells in vitro and were more abundant in the presence of $\mathrm{BM}$-infiltrating NB cells. However, whether these vesicles were secreted by NB or by BM resident cells could not be determined [109]. 


\subsubsection{Proteins}

The proteomic profile of exosomes derived by BM-infiltrating NB cells has been compared to that of exosomes generated by primary tumor NB cells [110]. Several proteins were found differentially expressed. Namely, exosomes isolated from BM-infiltrating NB cells contain more proteins involved in mitochondrial activity and fewer proteins involved in cell-cell adhesion and extracellular matrix assembly [110], fully confirming the results obtained by gene expression analysis of BM-infiltrating NB cells, in comparison with primary tumor cells $[15,44]$.

\subsubsection{MicroRNA}

MicroRNAs, important regulators of gene expression [111], have been found inside exosomes released by BM-infiltrating NB cells. Colletti et al. found elevated levels of miR-375 and demonstrated that this specific miRNA was responsible for the differentiation of BM MSCs in osteoblasts that may favor survival and proliferation of the metastatic cells [83].

Exosome-entrapped miRNAs were also found in blood from children with stage M NB [107]. The differential levels, before and after induction chemotherapy, of these exosome-entrapped miRNAs associate with response to therapy, suggesting a key role in inducing chemo-resistance [107].

Finally, miRNAs, known to be involved in mediating chemo-resistance of NB cells, have been searched in whole BM samples taken at diagnosis from children with stage $\mathrm{M}$ $\mathrm{NB}$, but none was found differentially expressed in responders and non-responders to induction chemotherapy [112]. These latter results, however, were likely due to the fact that miRNAs produced by BM resident cells hid the variations occurring in miRNAs produced by the BM-infiltrating NB cells. Therefore, studies using purified BM extracellular vesicles are needed to better evaluate whether specific miRNAs can drive chemo-resistance of metastatic cells.

\section{Conclusions}

From the studies referenced here, several aspects of the BM microenvironment in metastatic neuroblastoma remain to be elucidated. In view of the importance of BM infiltration in the prognosis of children with $\mathrm{NB}$, increased knowledge of the mechanisms involved in cell-cell interaction and on the role of soluble factors in mediating BM infiltration by NB cells and their survival and proliferation in BM, will allow finding new therapeutic targets and cure strategies for high-risk NB patients.

Author Contributions: Conceptualization, M.V.C., M.P., C.B., F.P., P.P., L.A.; data curation, M.V.C., M.P., C.B., F.P., P.P., L.A.; writing—original draft preparation, M.V.C., M.P., C.B., F.P., L.A.; writingreview and editing, M.V.C., M.P., C.B., F.P., P.P., L.A., V.B., E.C.; visualization, V.B., E.C.; funding acquisition, M.P., F.P. All authors have read and agreed to the published version of the manuscript.

Funding: This research received no external funding.

Institutional Review Board Statement: Ethical review and approval were waived for this study, due to its review character.

Informed Consent Statement: Patient consent was waived due to its review character.

Data Availability Statement: Data availability must be asked to the referenced Authors.

Acknowledgments: VB is recipient of a fellowship from Fondazione Italiana per la Lotta al Neuroblastoma-Genova and Associazione Oncologia Pediatrica (OPEN)-Napoli. EC is recipient of a fellowship from Associazione OPEN-Napoli and Associazione Italiana per la Ricerca sul Cancro, Investigator Grant n.18474 to MP., FP is recipient of Investigator Grant n.24397 from Associazione Italiana per la Ricerca sul Cancro.

Conflicts of Interest: The authors declare no conflict of interest. 


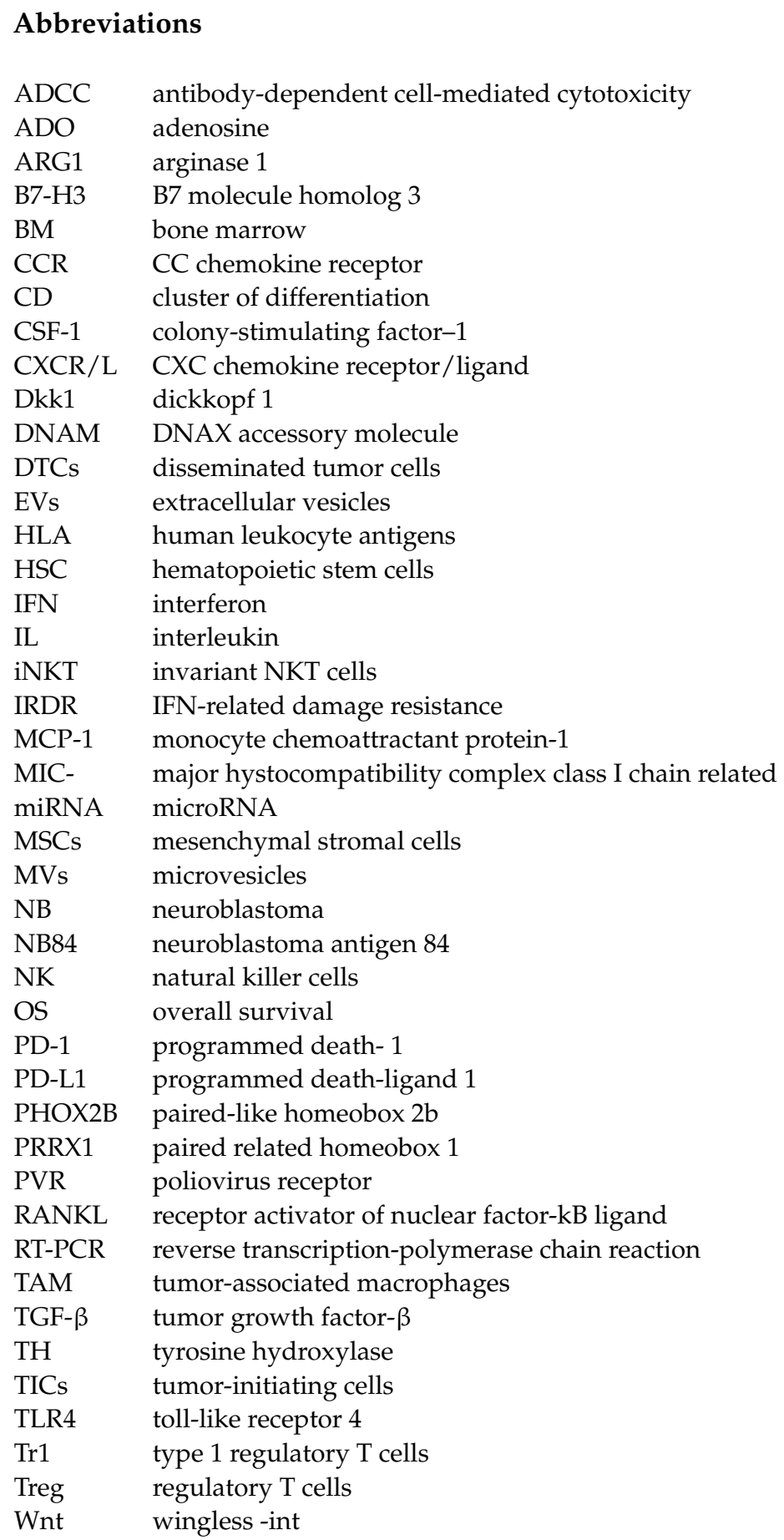

\section{References}

1. Louis, C.U.; Shohet, J.M. Neuroblastoma: Molecular pathogenesis and therapy. Annu. Rev. Med. 2015, 66, 49-63. [CrossRef]

2. Maris, J.M. Recent advances in neuroblastoma. N. Engl. J. Med. 2010, 362, 2202-2211. [CrossRef]

3. Matthay, K.K.; Maris, J.M.; Schleiermacher, G.; Nakagawara, A.; Mackall, C.L.; Diller, L.; Weiss, W.A. Neuroblastoma. Nat. Rev. Dis. Primers 2016, 2, 16078. [CrossRef] [PubMed]

4. Cheung, N.K.; Dyer, M.A. Neuroblastoma: Developmental biology, cancer genomics and immunotherapy. Nat. Rev. Cancer 2013, 13, 397-411. [CrossRef]

5. Vo, K.T.; Matthay, K.K.; Neuhaus, J.; London, W.B.; Hero, B.; Ambros, P.F.; Nakagawara, A.; Miniati, D.; Wheeler, K.; Pearson, A.D.; et al. Clinical, biologic, and prognostic differences on the basis of primary tumor site in neuroblastoma: A report from the international neuroblastoma risk group project. J. Clin. Oncol. 2014, 32, 3169-3176. [CrossRef] [PubMed] 
6. Monclair, T.; Brodeur, G.M.; Ambros, P.F.; Brisse, H.J.; Cecchetto, G.; Holmes, K.; Kaneko, M.; London, W.B.; Matthay, K.K.; Nuchtern, J.G.; et al. The International Neuroblastoma Risk Group (INRG) staging system: An INRG Task Force report. J. Clin. Oncol. 2009, 27, 298-303. [CrossRef] [PubMed]

7. Cohn, S.L.; Pearson, A.D.; London, W.B.; Monclair, T.; Ambros, P.F.; Brodeur, G.M.; Faldum, A.; Hero, B.; Iehara, T.; Machin, D.; et al. The International Neuroblastoma Risk Group (INRG) classification system: An INRG Task Force report. J. Clin. Oncol. 2009, 27, 289-297. [CrossRef] [PubMed]

8. De Bernardi, B.; Gerrard, M.; Boni, L.; Rubie, H.; Canete, A.; Di Cataldo, A.; Castel, V.; de Lacerda, A.F.; Ladenstein, R.; Ruud, E.; et al. Excellent outcome with reduced treatment for infants with disseminated neuroblastoma without MYCN gene amplification. J. Clin. Oncol. 2009, 27, 1034-1040. [CrossRef]

9. Ladenstein, R.; Potschger, U.; Pearson, A.D.J.; Brock, P.; Luksch, R.; Castel, V.; Yaniv, I.; Papadakis, V.; Laureys, G.; Malis, J.; et al. Busulfan and melphalan versus carboplatin, etoposide, and melphalan as high-dose chemotherapy for high-risk neuroblastoma (HR-NBL1/SIOPEN): An international, randomised, multi-arm, open-label, phase 3 trial. Lancet Oncol. 2017, 18, 500-514. [CrossRef]

10. Burchill, S.A.; Beiske, K.; Shimada, H.; Ambros, P.F.; Seeger, R.; Tytgat, G.A.; Brock, P.R.; Haber, M.; Park, J.R.; Berthold, F. Recommendations for the standardization of bone marrow disease assessment and reporting in children with neuroblastoma on behalf of the International Neuroblastoma Response Criteria Bone Marrow Working Group. Cancer 2017, 123, 1095-1105. [CrossRef]

11. Cohen, M.D. International criteria for neuroblastoma diagnosis, staging, and response to treatment. J. Clin. Oncol. 1994, 12, 1991-1993. [CrossRef]

12. Park, J.R.; Bagatell, R.; Cohn, S.L.; Pearson, A.D.; Villablanca, J.G.; Berthold, F.; Burchill, S.; Boubaker, A.; McHugh, K.; Nuchtern, J.G.; et al. Revisions to the International Neuroblastoma Response Criteria: A Consensus Statement From the National Cancer Institute Clinical Trials Planning Meeting. J. Clin. Oncol. 2017, 35, 2580-2587. [CrossRef] [PubMed]

13. Lode, H.N.; Xiang, R.; Varki, N.M.; Dolman, C.S.; Gillies, S.D.; Reisfeld, R.A. Targeted interleukin-2 therapy for spontaneous neuroblastoma metastases to bone marrow. J. Natl. Cancer Inst. 1997, 89, 1586-1594. [CrossRef] [PubMed]

14. Gregorio, A.; Corrias, M.V.; Castriconi, R.; Dondero, A.; Mosconi, M.; Gambini, C.; Moretta, A.; Moretta, L.; Bottino, C. Small round blue cell tumours: Diagnostic and prognostic usefulness of the expression of B7-H3 surface molecule. Histopathology 2008, 53, 73-80. [CrossRef]

15. Morandi, F.; Scaruffi, P.; Gallo, F.; Stigliani, S.; Moretti, S.; Bonassi, S.; Gambini, C.; Mazzocco, K.; Fardin, P.; Haupt, R.; et al. Bone marrow-infiltrating human neuroblastoma cells express high levels of calprotectin and HLA-G proteins. PLoS ONE 2012, 7, e29922. [CrossRef]

16. Rifatbegovic, F.; Abbasi, M.R.; Taschner-Mandl, S.; Kauer, M.; Weinhausel, A.; Handgretinger, R.; Ambros, P.F. Enriched Bone Marrow Derived Disseminated Neuroblastoma Cells Can Be a Reliable Source for Gene Expression Studies-A Validation Study. PLoS ONE 2015, 10, e0137995. [CrossRef]

17. Garaventa, A.; Parodi, S.; De Bernardi, B.; Dau, D.; Manzitti, C.; Conte, M.; Casale, F.; Viscardi, E.; Bianchi, M.; D'Angelo, P.; et al. Outcome of children with neuroblastoma after progression or relapse. A retrospective study of the Italian neuroblastoma registry. Eur. J. Cancer 2009, 45, 2835-2842. [CrossRef]

18. London, W.B.; Bagatell, R.; Weigel, B.J.; Fox, E.; Guo, D.; Van Ryn, C.; Naranjo, A.; Park, J.R. Historical time to disease progression and progression-free survival in patients with recurrent/refractory neuroblastoma treated in the modern era on Children's Oncology Group early-phase trials. Cancer 2017, 123, 4914-4923. [CrossRef]

19. Zhang, J.; Niu, C.; Ye, L.; Huang, H.; He, X.; Tong, W.G.; Ross, J.; Haug, J.; Johnson, T.; Feng, J.Q.; et al. Identification of the haematopoietic stem cell niche and control of the niche size. Nature 2003, 425, 836-841. [CrossRef]

20. Clines, G.A.; Guise, T.A. Molecular mechanisms and treatment of bone metastasis. Expert Rev. Mol. Med. 2008, 10, e7. [CrossRef]

21. Cruse, J.M.; Lewis, R.E.; Wang, H. Immunology Guidebook; Elsevier Academic Press: San Diego, CA, USA, $2004 ;$ pp. 47-124.

22. Swerts, K.; Ambros, P.F.; Brouzes, C.; Navarro, J.M.; Gross, N.; Rampling, D.; Schumacher-Kuckelkorn, R.; Sementa, A.R.; Ladenstein, R.; Beiske, K. Standardization of the immunocytochemical detection of neuroblastoma cells in bone marrow. $J$. Histochem. Cytochem. 2005, 53, 1433-1440. [CrossRef]

23. Viprey, V.F.; Lastowska, M.A.; Corrias, M.V.; Swerts, K.; Jackson, M.S.; Burchill, S.A. Minimal disease monitoring by QRT-PCR: Guidelines for identification and systematic validation of molecular markers prior to evaluation in prospective clinical trials. $J$. Pathol. 2008, 216, 245-252. [CrossRef]

24. Corrias, M.V.; Parodi, S.; Tchirkov, A.; Lammens, T.; Vicha, A.; Pasqualini, C.; Trager, C.; Yanez, Y.; Dallorso, S.; Varesio, L.; et al. Event-free survival of infants and toddlers enrolled in the HR-NBL-1/SIOPEN trial is associated with the level of neuroblastoma mRNAs at diagnosis. Pediatric Blood Cancer 2018, 65, e27052. [CrossRef]

25. Viprey, V.F.; Gregory, W.M.; Corrias, M.V.; Tchirkov, A.; Swerts, K.; Vicha, A.; Dallorso, S.; Brock, P.; Luksch, R.; Valteau-Couanet, D.; et al. Neuroblastoma mRNAs predict outcome in children with stage 4 neuroblastoma: A European HR-NBL1/SIOPEN study. J. Clin. Oncol. 2014, 32, 1074-1083. [CrossRef] [PubMed]

26. Marachelian, A.; Villablanca, J.G.; Liu, C.W.; Liu, B.; Goodarzian, F.; Lai, H.A.; Shimada, H.; Tran, H.C.; Parra, J.A.; Gallego, R.; et al. Expression of Five Neuroblastoma Genes in Bone Marrow or Blood of Patients with Relapsed/Refractory Neuroblastoma Provides a New Biomarker for Disease and Prognosis. Clin. Cancer Res. 2017, 23, 5374-5383. [CrossRef] [PubMed] 
27. Airoldi, I.; Lualdi, S.; Bruno, S.; Raffaghello, L.; Occhino, M.; Gambini, C.; Pistoia, V.; Corrias, M.V. Expression of costimulatory molecules in human neuroblastoma. Evidence that CD40+ neuroblastoma cells undergo apoptosis following interaction with CD40L. Br. J. Cancer 2003, 88, 1527-1536. [CrossRef]

28. Corrias, M.V.; Occhino, M.; Croce, M.; De Ambrosis, A.; Pistillo, M.P.; Bocca, P.; Pistoia, V.; Ferrini, S. Lack of HLA-class I antigens in human neuroblastoma cells: Analysis of its relationship to TAP and tapasin expression. Tissue Antigens 2001, 57, 110-117. [CrossRef]

29. Croce, M.; De Ambrosis, A.; Corrias, M.V.; Pistoia, V.; Occhino, M.; Meazza, R.; Giron-Michel, J.; Azzarone, B.; Accolla, R.S.; Ferrini, S. Different levels of control prevent interferon-gamma-inducible HLA-class II expression in human neuroblastoma cells. Oncogene 2003, 22, 7848-7857. [CrossRef]

30. Ponzoni, M.; Guarnaccia, F.; Corrias, M.V.; Cornaglia-Ferraris, P. Uncoordinate induction and differential regulation of HLA class-I and class-II expression by gamma-interferon in differentiating human neuroblastoma cells. Int. J. Cancer 1993, 55, 817-823. [CrossRef]

31. Vitale, M.; Cantoni, C.; Della Chiesa, M.; Ferlazzo, G.; Carlomagno, S.; Pende, D.; Falco, M.; Pessino, A.; Muccio, L.; De Maria, A.; et al. An Historical Overview: The Discovery of How NK Cells Can Kill Enemies, Recruit Defense Troops, and More. Front. Immunol. 2019, 10, 1415. [CrossRef] [PubMed]

32. Castriconi, R.; Dondero, A.; Augugliaro, R.; Cantoni, C.; Carnemolla, B.; Sementa, A.R.; Negri, F.; Conte, R.; Corrias, M.V.; Moretta, L.; et al. Identification of 4Ig-B7-H3 as a neuroblastoma-associated molecule that exerts a protective role from an NK cell-mediated lysis. Proc. Natl. Acad. Sci. USA 2004, 101, 12640-12645. [CrossRef]

33. Castriconi, R.; Dondero, A.; Corrias, M.V.; Lanino, E.; Pende, D.; Moretta, L.; Bottino, C.; Moretta, A. Natural killer cell-mediated killing of freshly isolated neuroblastoma cells: Critical role of DNAX accessory molecule-1-poliovirus receptor interaction. Cancer Res. 2004, 64, 9180-9184. [CrossRef]

34. Raffaghello, L.; Prigione, I.; Airoldi, I.; Camoriano, M.; Levreri, I.; Gambini, C.; Pende, D.; Steinle, A.; Ferrone, S.; Pistoia, V. Downregulation and/or release of NKG2D ligands as immune evasion strategy of human neuroblastoma. Neoplasia 2004, 6, 558-568. [CrossRef] [PubMed]

35. Castriconi, R.; Dondero, A.; Bellora, F.; Moretta, L.; Castellano, A.; Locatelli, F.; Corrias, M.V.; Moretta, A.; Bottino, C. Neuroblastoma-derived TGF-beta1 modulates the chemokine receptor repertoire of human resting NK cells. J. Immunol. 2013, 190, 5321-5328. [CrossRef]

36. Allen, S.J.; Crown, S.E.; Handel, T.M. Chemokine: Receptor structure, interactions, and antagonism. Annu. Rev. Immunol. 2007, 25, 787-820. [CrossRef]

37. Airoldi, I.; Cocco, C.; Morandi, F.; Prigione, I.; Pistoia, V. CXCR5 may be involved in the attraction of human metastatic neuroblastoma cells to the bone marrow. Cancer Immunol. Immunother. 2008, 57, 541-548. [CrossRef]

38. Airoldi, I.; Raffaghello, L.; Piovan, E.; Cocco, C.; Carlini, B.; Amadori, A.; Corrias, M.V.; Pistoia, V. CXCL12 does not attract CXCR4+ human metastatic neuroblastoma cells: Clinical implications. Clin. Cancer Res. 2006, 12, 77-82. [CrossRef]

39. Goldberg-Bittman, L.; Sagi-Assif, O.; Meshel, T.; Nevo, I.; Levy-Nissenbaum, O.; Yron, I.; Witz, I.P.; Ben-Baruch, A. Cellular characteristics of neuroblastoma cells: Regulation by the ELR-CXC chemokine CXCL10 and expression of a CXCR3-like receptor. Cytokine 2005, 29, 105-117. [CrossRef]

40. Hansford, L.M.; McKee, A.E.; Zhang, L.; George, R.E.; Gerstle, J.T.; Thorner, P.S.; Smith, K.M.; Look, A.T.; Yeger, H.; Miller, F.D.; et al. Neuroblastoma cells isolated from bone marrow metastases contain a naturally enriched tumor-initiating cell. Cancer Res. 2007, 67, 11234-11243. [CrossRef]

41. Morozova, O.; Vojvodic, M.; Grinshtein, N.; Hansford, L.M.; Blakely, K.M.; Maslova, A.; Hirst, M.; Cezard, T.; Morin, R.D.; Moore, R.; et al. System-level analysis of neuroblastoma tumor-initiating cells implicates AURKB as a novel drug target for neuroblastoma. Clin. Cancer Res. 2010, 16, 4572-4582. [CrossRef]

42. Mohlin, S.; Pietras, A.; Wigerup, C.; Ora, I.; Andang, M.; Nilsson, K.; Olofsson, T.; Gisselsson, D.; Pahlman, S. Tumor-initiating cells in childhood neuroblastoma-letter. Cancer Res. 2012, 72, 821-822, author reply 823. [CrossRef]

43. Coulon, A.; Flahaut, M.; Muhlethaler-Mottet, A.; Meier, R.; Liberman, J.; Balmas-Bourloud, K.; Nardou, K.; Yan, P.; Tercier, S.; Joseph, J.M.; et al. Functional sphere profiling reveals the complexity of neuroblastoma tumor-initiating cell model. Neoplasia 2011, 13, 991-1004. [CrossRef]

44. Rifatbegovic, F.; Frech, C.; Abbasi, M.R.; Taschner-Mandl, S.; Weiss, T.; Schmidt, W.M.; Schmidt, I.; Ladenstein, R.; Ambros, I.M.; Ambros, P.F. Neuroblastoma cells undergo transcriptomic alterations upon dissemination into the bone marrow and subsequent tumor progression. Int. J. Cancer 2018, 142, 297-307. [CrossRef]

45. Stigliani, S.; Scaruffi, P.; Lagazio, C.; Persico, L.; Carlini, B.; Varesio, L.; Morandi, F.; Morini, M.; Gigliotti, A.R.; Esposito, M.R.; et al. Deregulation of focal adhesion pathway mediated by miR-659-3p is implicated in bone marrow infiltration of stage $\mathrm{M}$ neuroblastoma patients. Oncotarget 2015, 6, 13295-13308. [CrossRef]

46. Rouas-Freiss, N.; Moreau, P.; Menier, C.; LeMaoult, J.; Carosella, E.D. Expression of tolerogenic HLA-G molecules in cancer prevents antitumor responses. Semin. Cancer Biol. 2007, 17, 413-421. [CrossRef]

47. Morandi, F.; Levreri, I.; Bocca, P.; Galleni, B.; Raffaghello, L.; Ferrone, S.; Prigione, I.; Pistoia, V. Human neuroblastoma cells trigger an immunosuppressive program in monocytes by stimulating soluble HLA-G release. Cancer Res. 2007, 67, 6433-6441. [CrossRef] 
48. Ghavami, S.; Rashedi, I.; Dattilo, B.M.; Eshraghi, M.; Chazin, W.J.; Hashemi, M.; Wesselborg, S.; Kerkhoff, C.; Los, M. S100A8/A9 at low concentration promotes tumor cell growth via RAGE ligation and MAP kinase-dependent pathway. J. Leukoc. Biol. 2008, 83, 1484-1492. [CrossRef]

49. Hiratsuka, S.; Watanabe, A.; Sakurai, Y.; Akashi-Takamura, S.; Ishibashi, S.; Miyake, K.; Shibuya, M.; Akira, S.; Aburatani, H.; Maru, Y. The S100A8-serum amyloid A3-TLR4 paracrine cascade establishes a pre-metastatic phase. Nat. Cell Biol. 2008, 10, 1349-1355. [CrossRef]

50. Boeva, V.; Louis-Brennetot, C.; Peltier, A.; Durand, S.; Pierre-Eugene, C.; Raynal, V.; Etchevers, H.C.; Thomas, S.; Lermine, A.; Daudigeos-Dubus, E.; et al. Heterogeneity of neuroblastoma cell identity defined by transcriptional circuitries. Nat. Genet. 2017, 49, 1408-1413. [CrossRef]

51. Decaesteker, B.; Denecker, G.; Van Neste, C.; Dolman, E.M.; Van Loocke, W.; Gartlgruber, M.; Nunes, C.; De Vloed, F.; Depuydt, P.; Verboom, K.; et al. TBX2 is a neuroblastoma core regulatory circuitry component enhancing MYCN/FOXM1 reactivation of DREAM targets. Nat. Commun. 2018, 9, 4866. [CrossRef]

52. Rajbhandari, P.; Lopez, G.; Capdevila, C.; Salvatori, B.; Yu, J.; Rodriguez-Barrueco, R.; Martinez, D.; Yarmarkovich, M.; WeichertLeahey, N.; Abraham, B.J.; et al. Cross-Cohort Analysis Identifies a TEAD4-MYCN Positive Feedback Loop as the Core Regulatory Element of High-Risk Neuroblastoma. Cancer Discov. 2018, 8, 582-599. [CrossRef]

53. Van Groningen, T.; Akogul, N.; Westerhout, E.M.; Chan, A.; Hasselt, N.E.; Zwijnenburg, D.A.; Broekmans, M.; Stroeken, P.; Haneveld, F.; Hooijer, G.K.J.; et al. A NOTCH feed-forward loop drives reprogramming from adrenergic to mesenchymal state in neuroblastoma. Nat. Commun. 2019, 10, 1530. [CrossRef]

54. Van Groningen, T.; Koster, J.; Valentijn, L.J.; Zwijnenburg, D.A.; Akogul, N.; Hasselt, N.E.; Broekmans, M.; Haneveld, F.; Nowakowska, N.E.; Bras, J.; et al. Neuroblastoma is composed of two super-enhancer-associated differentiation states. Nat. Genet. 2017, 49, 1261-1266. [CrossRef] [PubMed]

55. Canzonetta, C.; Pelosi, A.; Di Matteo, S.; Veneziani, I.; Tumino, N.; Vacca, P.; Munari, E.; Pezzullo, M.; Theuer, C.; De Vito, R.; et al. Identification of neuroblastoma cell lines with uncommon TAZ $(+) /$ mesenchymal stromal cell phenotype with strong suppressive activity on natural killer cells. J. Immunother. Cancer 2021, 9. [CrossRef] [PubMed]

56. Furlan, A.; Dyachuk, V.; Kastriti, M.E.; Calvo-Enrique, L.; Abdo, H.; Hadjab, S.; Chontorotzea, T.; Akkuratova, N.; Usoskin, D.; Kamenev, D.; et al. Multipotent peripheral glial cells generate neuroendocrine cells of the adrenal medulla. Science 2017, 357, eaal3753. [CrossRef]

57. Dong, R.; Yang, R.; Zhan, Y.; Lai, H.D.; Ye, C.J.; Yao, X.Y.; Luo, W.Q.; Cheng, X.M.; Miao, J.J.; Wang, J.F.; et al. Single-Cell Characterization of Malignant Phenotypes and Developmental Trajectories of Adrenal Neuroblastoma. Cancer Cell 2020, 38, 716-733.e6. [CrossRef] [PubMed]

58. Hanemaaijer, E.S.; Margaritis, T.; Sanders, K.; Bos, F.L.; Candelli, T.; Al-Saati, H.; van Noesel, M.M.; Meyer-Wentrup, F.A.G.; van de Wetering, M.; Holstege, F.C.P.; et al. Single-cell atlas of developing murine adrenal gland reveals relation of Schwann cell precursor signature to neuroblastoma phenotype. Proc. Natl. Acad. Sci. USA 2021, 118, e2022350118. [CrossRef]

59. Kildisiute, G.; Kholosy, W.M.; Young, M.D.; Roberts, K.; Elmentaite, R.; van Hooff, S.R.; Pacyna, C.N.; Khabirova, E.; Piapi, A.; Thevanesan, C.; et al. Tumor to normal single-cell mRNA comparisons reveal a pan-neuroblastoma cancer cell. Sci. Adv. 2021, 7, eabd3311. [CrossRef] [PubMed]

60. Jansky, S.; Sharma, A.K.; Korber, V.; Quintero, A.; Toprak, U.H.; Wecht, E.M.; Gartlgruber, M.; Greco, A.; Chomsky, E.; Grunewald, T.G.P.; et al. Single-cell transcriptomic analyses provide insights into the developmental origins of neuroblastoma. Nat. Genet. 2021, 53, 683-693. [CrossRef] [PubMed]

61. Kameneva, P.; Artemov, A.V.; Kastriti, M.E.; Faure, L.; Olsen, T.K.; Otte, J.; Erickson, A.; Semsch, B.; Andersson, E.R.; Ratz, M.; et al. Single-cell transcriptomics of human embryos identifies multiple sympathoblast lineages with potential implications for neuroblastoma origin. Nat. Genet. 2021, 53, 694-706. [CrossRef] [PubMed]

62. Martinez, C.; Hofmann, T.J.; Marino, R.; Dominici, M.; Horwitz, E.M. Human bone marrow mesenchymal stromal cells express the neural ganglioside GD2: A novel surface marker for the identification of MSCs. Blood 2007, 109, 4245-4248. [CrossRef] [PubMed]

63. Piskareva, O.; Harvey, H.; Nolan, J.; Conlon, R.; Alcock, L.; Buckley, P.; Dowling, P.; Henry, M.; O'Sullivan, F.; Bray, I.; et al. The development of cisplatin resistance in neuroblastoma is accompanied by epithelial to mesenchymal transition in vitro. Cancer Lett. 2015, 364, 142-155. [CrossRef] [PubMed]

64. Nolan, J.C.; Salvucci, M.; Carberry, S.; Barat, A.; Segura, M.F.; Fenn, J.; Prehn, J.H.M.; Stallings, R.L.; Piskareva, O. A ContextDependent Role for MiR-124-3p on Cell Phenotype, Viability and Chemosensitivity in Neuroblastoma in vitro. Front. Cell Dev. Biol. 2020, 8, 559553. [CrossRef]

65. Gavin, C.; Geerts, N.; Cavanagh, B.; Haynes, M.; Reynolds, C.P.; Loessner, D.; Ewald, A.J.; Piskareva, O. Neuroblastoma Invasion Strategies Are Regulated by the Extracellular Matrix. Cancers 2021, 13, 736. [CrossRef]

66. Hochheuser, C.; Windt, L.J.; Kunze, N.Y.; de Vos, D.L.; Tytgat, G.A.M.; Voermans, C.; Timmerman, I. Mesenchymal Stromal Cells in Neuroblastoma: Exploring Crosstalk and Therapeutic Implications. Stem. Cells Dev. 2021, 30, 59-78. [CrossRef] [PubMed]

67. Morandi, F.; Barco, S.; Stigliani, S.; Croce, M.; Persico, L.; Lagazio, C.; Scuderi, F.; Belli, M.L.; Montera, M.; Cangemi, G.; et al. Altered erythropoiesis and decreased number of erythrocytes in children with neuroblastoma. Oncotarget 2017, 8, 53194-53209. [CrossRef] 
68. Morandi, F.; Pozzi, S.; Barco, S.; Cangemi, G.; Amoroso, L.; Carlini, B.; Pistoia, V.; Corrias, M.V. CD4(+)CD25(hi)CD127(-) Treg and CD4(+)CD45R0(+)CD49b(+)LAG3(+) Tr1 cells in bone marrow and peripheral blood samples from children with neuroblastoma. Oncoimmunology 2016, 5, e1249553. [CrossRef]

69. Godfrey, D.I.; MacDonald, H.R.; Kronenberg, M.; Smyth, M.J.; Van Kaer, L. NKT cells: What's in a name? Nat. Rev. Immunol. 2004, 4, 231-237. [CrossRef]

70. Song, L.; Asgharzadeh, S.; Salo, J.; Engell, K.; Wu, H.W.; Sposto, R.; Ara, T.; Silverman, A.M.; DeClerck, Y.A.; Seeger, R.C.; et al. Valpha24-invariant NKT cells mediate antitumor activity via killing of tumor-associated macrophages. J. Clin. Investig. 2009, 119, 1524-1536. [CrossRef]

71. Asgharzadeh, S.; Salo, J.A.; Ji, L.; Oberthuer, A.; Fischer, M.; Berthold, F.; Hadjidaniel, M.; Liu, C.W.; Metelitsa, L.S.; Pique-Regi, R.; et al. Clinical significance of tumor-associated inflammatory cells in metastatic neuroblastoma. J. Clin. Oncol. 2012, 30, 3525-3532. [CrossRef]

72. Hadjidaniel, M.D.; Muthugounder, S.; Hung, L.T.; Sheard, M.A.; Shirinbak, S.; Chan, R.Y.; Nakata, R.; Borriello, L.; Malvar, J.; Kennedy, R.J.; et al. Tumor-associated macrophages promote neuroblastoma via STAT3 phosphorylation and up-regulation of c-MYC. Oncotarget 2017, 8, 91516-91529. [CrossRef] [PubMed]

73. Fend, L.; Accart, N.; Kintz, J.; Cochin, S.; Reymann, C.; Le Pogam, F.; Marchand, J.B.; Menguy, T.; Slos, P.; Rooke, R.; et al. Therapeutic effects of anti-CD115 monoclonal antibody in mouse cancer models through dual inhibition of tumor-associated macrophages and osteoclasts. PLoS ONE 2013, 8, e73310. [CrossRef] [PubMed]

74. Metelitsa, L.S.; Wu, H.W.; Wang, H.; Yang, Y.; Warsi, Z.; Asgharzadeh, S.; Groshen, S.; Wilson, S.B.; Seeger, R.C. Natural killer T cells infiltrate neuroblastomas expressing the chemokine CCL2. J. Exp. Med. 2004, 199, 1213-1221. [CrossRef] [PubMed]

75. Sohara, Y.; Shimada, H.; DeClerck, Y.A. Mechanisms of bone invasion and metastasis in human neuroblastoma. Cancer Lett. 2005, 228, 203-209. [CrossRef] [PubMed]

76. Chen, Y.; Alman, B.A. Wnt pathway, an essential role in bone regeneration. J. Cell Biochem. 2009, 106, 353-362. [CrossRef]

77. Granchi, D.; Baglio, S.R.; Amato, I.; Giunti, A.; Baldini, N. Paracrine inhibition of osteoblast differentiation induced by neuroblastoma cells. Int. J. Cancer 2008, 123, 1526-1535. [CrossRef]

78. Granchi, D.; Corrias, M.V.; Garaventa, A.; Baglio, S.R.; Cangemi, G.; Carlini, B.; Paolucci, P.; Giunti, A.; Baldini, N. Neuroblastoma and bone metastases: Clinical significance and prognostic value of Dickkopf 1 plasma levels. Bone 2011, 48, 152-159. [CrossRef] [PubMed]

79. Scaruffi, P.; Morandi, F.; Gallo, F.; Stigliani, S.; Parodi, S.; Moretti, S.; Bonassi, S.; Fardin, P.; Garaventa, A.; Zanazzo, G.; et al. Bone marrow of neuroblastoma patients shows downregulation of CXCL12 expression and presence of IFN signature. Pediatric Blood Cancer 2012, 59, 44-51. [CrossRef]

80. Borriello, L.; Nakata, R.; Sheard, M.A.; Fernandez, G.E.; Sposto, R.; Malvar, J.; Blavier, L.; Shimada, H.; Asgharzadeh, S.; Seeger, R.C.; et al. Cancer-Associated Fibroblasts Share Characteristics and Protumorigenic Activity with Mesenchymal Stromal Cells. Cancer Res. 2017, 77, 5142-5157. [CrossRef]

81. Lifshitz, V.; Priceman, S.J.; Li, W.; Cherryholmes, G.; Lee, H.; Makovski-Silverstein, A.; Borriello, L.; DeClerck, Y.A.; Yu, H. Sphingosine-1-Phosphate Receptor-1 Promotes Environment-Mediated and Acquired Chemoresistance. Mol. Cancer Ther. 2017, 16, 2516-2527. [CrossRef]

82. Nakata, R.; Shimada, H.; Fernandez, G.E.; Fanter, R.; Fabbri, M.; Malvar, J.; Zimmermann, P.; DeClerck, Y.A. Contribution of neuroblastoma-derived exosomes to the production of pro-tumorigenic signals by bone marrow mesenchymal stromal cells. $J$. Extracell. Vesicles 2017, 6, 1332941. [CrossRef]

83. Colletti, M.; Tomao, L.; Galardi, A.; Paolini, A.; Di Paolo, V.; De Stefanis, C.; Mascio, P.; Nazio, F.; Petrini, S.; Castellano, A.; et al. Neuroblastoma-secreted exosomes carrying miR-375 promote osteogenic differentiation of bone-marrow mesenchymal stromal cells. J. Extracell. Vesicles 2020, 9, 1774144. [CrossRef]

84. Hochheuser, C.; Kunze, N.Y.; Tytgat, G.A.M.; Voermans, C.; Timmerman, I. The Potential of Mesenchymal Stromal Cells in Neuroblastoma Therapy for Delivery of Anti-Cancer Agents and Hematopoietic Recovery. J. Pers. Med. 2021, 11, 161. [CrossRef]

85. Burchill, S.A.; Berry, A.; Roundhill, E.; Cullinane, C.; Elliott, M.; Tweddle, D.; Gray, J.; Ladenstein, R. Self-Renewing Neuroblastoma Cells of the Bone Marrow Share a Mesenchymal Phenotype Which is Associated with Poor Outcome: An NCRI CCL CSG Neuroblastoma Group Study. In Proceedings of the Conference on Advances in Neuroblastoma Research, Virtual. 25-27 January 2021. PA5.3.

86. Yu, A.L.; Gilman, A.L.; Ozkaynak, M.F.; London, W.B.; Kreissman, S.G.; Chen, H.X.; Smith, M.; Anderson, B.; Villablanca, J.G.; Matthay, K.K.; et al. Anti-GD2 antibody with GM-CSF, interleukin-2, and isotretinoin for neuroblastoma. N. Engl. J. Med. 2010, 363, 1324-1334. [CrossRef]

87. Kushner, B.H.; Cheung, I.Y.; Modak, S.; Basu, E.M.; Roberts, S.S.; Cheung, N.K. Humanized 3F8 Anti-GD2 Monoclonal Antibody Dosing With Granulocyte-Macrophage Colony-Stimulating Factor in Patients With Resistant Neuroblastoma: A Phase 1 Clinical Trial. JAMA Oncol. 2018, 4, 1729-1735. [CrossRef] [PubMed]

88. Tarek, N.; Le Luduec, J.B.; Gallagher, M.M.; Zheng, J.; Venstrom, J.M.; Chamberlain, E.; Modak, S.; Heller, G.; Dupont, B.; Cheung, N.K.; et al. Unlicensed NK cells target neuroblastoma following anti-GD2 antibody treatment. J. Clin. Investig. 2012, 122, 3260-3270. [CrossRef] 
89. Wu, H.W.; Sheard, M.A.; Malvar, J.; Fernandez, G.E.; DeClerck, Y.A.; Blavier, L.; Shimada, H.; Theuer, C.P.; Sposto, R.; Seeger, R.C. Anti-CD105 Antibody Eliminates Tumor Microenvironment Cells and Enhances Anti-GD2 Antibody Immunotherapy of Neuroblastoma with Activated Natural Killer Cells. Clin. Cancer Res. 2019, 25, 4761-4774. [CrossRef] [PubMed]

90. Mendez-Ferrer, S.; Lucas, D.; Battista, M.; Frenette, P.S. Haematopoietic stem cell release is regulated by circadian oscillations. Nature 2008, 452, 442-447. [CrossRef] [PubMed]

91. Geminder, H.; Sagi-Assif, O.; Goldberg, L.; Meshel, T.; Rechavi, G.; Witz, I.P.; Ben-Baruch, A. A possible role for CXCR4 and its ligand, the CXC chemokine stromal cell-derived factor-1, in the development of bone marrow metastases in neuroblastoma. J. Immunol. 2001, 167, 4747-4757. [CrossRef]

92. Meier, R.; Muhlethaler-Mottet, A.; Flahaut, M.; Coulon, A.; Fusco, C.; Louache, F.; Auderset, K.; Bourloud, K.B.; Daudigeos, E.; Ruegg, C.; et al. The chemokine receptor CXCR4 strongly promotes neuroblastoma primary tumour and metastatic growth, but not invasion. PLoS ONE 2007, 2, e1016. [CrossRef]

93. Opdal, S.H. Cytokines, Infection, and Immunity. In SIDS Sudden Infant and Early Childhood Death: The Past, the Present and the Future; Duncan, J.R., Byard, R.W., Eds.; University of Adelaide Press: Adelaide, Australia, 2018.

94. Jonasch, E.; Haluska, F.G. Interferon in oncological practice: Review of interferon biology, clinical applications, and toxicities. Oncologist 2001, 6, 34-55. [CrossRef]

95. Corrias, M.V.; Gribaudo, G.; Guarnaccia, F.; Ponzoni, M. Induction of 2.5 OAS gene expression and activity is not sufficient for IFN-gamma-induced neuroblastoma cell differentiation. Int. J. Cancer 1995, 62, 223-229. [CrossRef]

96. Dondero, A.; Pastorino, F.; Della Chiesa, M.; Corrias, M.V.; Morandi, F.; Pistoia, V.; Olive, D.; Bellora, F.; Locatelli, F.; Castellano, A.; et al. PD-L1 expression in metastatic neuroblastoma as an additional mechanism for limiting immune surveillance. Oncoimmunology 2016, 5, e1064578. [CrossRef] [PubMed]

97. Ara, T.; Declerck, Y.A. Interleukin-6 in bone metastasis and cancer progression. Eur. J. Cancer 2010, 46, 1223-1231. [CrossRef] [PubMed]

98. Ara, T.; Nakata, R.; Sheard, M.A.; Shimada, H.; Buettner, R.; Groshen, S.G.; Ji, L.; Yu, H.; Jove, R.; Seeger, R.C.; et al. Critical role of STAT3 in IL-6-mediated drug resistance in human neuroblastoma. Cancer Res. 2013, 73, 3852-3864. [CrossRef]

99. Morandi, F.; Croce, M.; Cangemi, G.; Barco, S.; Rigo, V.; Carlini, B.; Amoroso, L.; Pistoia, V.; Ferrini, S.; Corrias, M.V. IL-10 and ARG-1 concentrations in bone marrow and peripheral blood of metastatic neuroblastoma patients do not associate with clinical outcome. J. Immunol. Res. 2015, 2015, 718975. [CrossRef]

100. Le Bouteiller, P.; Lenfant, F. Antigen-presenting function(s) of the non-classical HLA-E, -F and -G class I molecules: The beginning of a story. Res. Immunol. 1996, 147, 301-313. [CrossRef]

101. Morandi, F.; Cangemi, G.; Barco, S.; Amoroso, L.; Giuliano, M.; Gigliotti, A.R.; Pistoia, V.; Corrias, M.V. Plasma levels of soluble HLA-E and HLA-F at diagnosis may predict overall survival of neuroblastoma patients. Biomed. Res. Int. 2013, $2013,956878$. [CrossRef]

102. Morandi, F.; Pozzi, S.; Carlini, B.; Amoroso, L.; Pistoia, V.; Corrias, M.V. Soluble HLA-G and HLA-E Levels in Bone Marrow Plasma Samples Are Related to Disease Stage in Neuroblastoma Patients. J. Immunol. Res. 2016, 2016, 7465741. [CrossRef] [PubMed]

103. Kanada, M.; Bachmann, M.H.; Hardy, J.W.; Frimannson, D.O.; Bronsart, L.; Wang, A.; Sylvester, M.D.; Schmidt, T.L.; Kaspar, R.L.; Butte, M.J.; et al. Differential fates of biomolecules delivered to target cells via extracellular vesicles. Proc. Natl. Acad. Sci. USA 2015, 112, E1433-E1442. [CrossRef]

104. Gopal, S.K.; Greening, D.W.; Rai, A.; Chen, M.; Xu, R.; Shafiq, A.; Mathias, R.A.; Zhu, H.J.; Simpson, R.J. Extracellular vesicles: Their role in cancer biology and epithelial-mesenchymal transition. Biochem. J. 2017, 474, 21-45. [CrossRef]

105. Gyorgy, B.; Szabo, T.G.; Pasztoi, M.; Pal, Z.; Misjak, P.; Aradi, B.; Laszlo, V.; Pallinger, E.; Pap, E.; Kittel, A.; et al. Membrane vesicles, current state-of-the-art: Emerging role of extracellular vesicles. Cell Mol. Life Sci. 2011, 68, 2667-2688. [CrossRef] [PubMed]

106. Marimpietri, D.; Petretto, A.; Raffaghello, L.; Pezzolo, A.; Gagliani, C.; Tacchetti, C.; Mauri, P.; Melioli, G.; Pistoia, V. Proteome profiling of neuroblastoma-derived exosomes reveal the expression of proteins potentially involved in tumor progression. PLoS ONE 2013, 8, e75054. [CrossRef] [PubMed]

107. Morini, M.; Cangelosi, D.; Segalerba, D.; Marimpietri, D.; Raggi, F.; Castellano, A.; Fruci, D.; de Mora, J.F.; Canete, A.; Yanez, Y.; et al. Exosomal microRNAs from Longitudinal Liquid Biopsies for the Prediction of Response to Induction Chemotherapy in High-Risk Neuroblastoma Patients: A Proof of Concept SIOPEN Study. Cancers 2019, 11, 1476. [CrossRef]

108. Horenstein, A.L.; Chillemi, A.; Zaccarello, G.; Bruzzone, S.; Quarona, V.; Zito, A.; Serra, S.; Malavasi, F. A CD38/CD203a/CD73 ectoenzymatic pathway independent of CD39 drives a novel adenosinergic loop in human T lymphocytes. Oncoimmunology 2013, 2, e26246. [CrossRef]

109. Morandi, F.; Marimpietri, D.; Horenstein, A.L.; Corrias, M.V.; Malavasi, F. Microvesicles expressing adenosinergic ectoenzymes and their potential role in modulating bone marrow infiltration by neuroblastoma cells. Oncoimmunology 2019, 8, e1574198. [CrossRef]

110. Colletti, M.; Petretto, A.; Galardi, A.; Di Paolo, V.; Tomao, L.; Lavarello, C.; Inglese, E.; Bruschi, M.; Lopez, A.A.; Pascucci, L.; et al. Proteomic Analysis of Neuroblastoma-Derived Exosomes: New Insights into a Metastatic Signature. Proteomics 2017, 17. [CrossRef] 
111. Flynt, A.S.; Lai, E.C. Biological principles of microRNA-mediated regulation: Shared themes amid diversity. Nat. Rev. Genet. 2008, 9, 831-842. [CrossRef]

112. Marengo, B.; Pulliero, A.; Corrias, M.V.; Leardi, R.; Farinini, E.; Fronza, G.; Menichini, P.; Monti, P.; Monteleone, L.; Valenti, G.E.; et al. Potential Role of miRNAs in the Acquisition of Chemoresistance in Neuroblastoma. J. Pers. Med. 2021, 11, 107. [CrossRef] [PubMed] 